\title{
Pemetaan partisipatif dalam mitigasi kebencanaan banjir dan longsor di Kelurahan Pringgokusuman Kota Yogyakarta
}

\section{(Participatory mapping of flood and landslide disaster mitigation in Pringgokusuman Village, Yogyakarta City)}

\author{
Ika Afianita Suherningtyas*1, Afrinia Lisditya Permatasari*, Erik Febriarta** \\ * Univeritas Amikom Yogyakarta, Jl. Ringroad Utara Depok Yogyakarta, 55283, Indonesia \\ ** Palawa Karya, Jl. Damai, Prujakan, Ngaglik, Sleman, Yogyakarta 55581, Indonesia \\ ${ }^{1}$ Corresponding author, Surel: ikaafianita@amikom.ac.id
}

Paper received: 11-04-2021; revised: 18-06-2021; accepted: 18-11-2021

\begin{abstract}
Pringgokusuman Village is geographically located on the bank of the Winongo River which originates from the Merapi Volcano, so it has the potential risk of lahar floods and landslides. On the other hand, this village has a high density level which is dominated by 87 percent settlements area. The purpose of the study was to compile a participatory disaster map for flood and landslide disaster mitigation in Pringgokusuman Village, Yogyakarta City as an effort to support disaster mitigation learning and education for the community. The participatory mapping was carried out with indepth interview and Focus Group Discussion (FGD) activities focusing on flood and landslide. The results of the participatory disaster mapping include basic disaster information, the number of disaster events, the potential and risks of disasters that occur. The analysis of the results was analyzed qualitatively and then added with spatial information (spatial) with areas regarding disasters and potential disasters. The results of the FGD showed that the most common disasters were overflowing floods from the Winongo river and landslide along. This research can be used to supplement Geography lessons on the disaster theme.
\end{abstract}

Keywords: cities; disaster mitigation; risk reduction

\begin{abstract}
Abstrak
Kelurahan Pringgokusuman secara geografis berada di bantaran penggal Sungai Winongo yang berhulu dari Gunung Merapi, sehingga memiliki potensi risiko bencana banjir lahar dan tanah longsor. Disisi lain kelurahan ini memiliki tingkat kepadatan yang tinggi yang didominasi permukiman 87 persen. Tujuan penelitian ini adalah menyusun peta bencana secara partisipatif untuk mitigasi kebencanaan banjir dan longsor di Kelurahan Pringgokusuman Kota Yogyakarta sebagai upaya mendukung pembelajaran dan pendidikan mitigasi bencana untuk masyarakat. Pemetaan partisipatif dilakukan dengan wawancara mendalam dan kegiatan Fokus Grup Diskusi (FGD) berfokus pada bencana banjir dan longsor. Hasil dari pemetaan partisipatif kebencaan tersebut antara lain informasi dasar kebencanaan, jumlah kejadian bencana, potensi dan risiko bencana yang terjadi. Analisis hasil dilakukan secara deskriptif kualitatif kemudian ditambahkan informasi keruangan (spasial) dengan informasi area. Hasil FGD menunjukkan bencana yang sering terjadi adalah banjir luapan dai sungai Winongo dan longsor di sepanjang Winongo dan saluran selokan. Penelitian ini dapat menjadi suplemen dalam pembelajaran Geografi terkait tema bencana.
\end{abstract}

Kata kunci: perkotaan; mitigasi bencana; pengurangan risiko 


\section{Pendahuluan}

Kota Yogyakarta merupakan wilayah kota yang mengalami perkembangan pesat (Rachmawati et al., 2018). Ciri perkotaan telah tampak di wilayah Kota Yogyakarta, ditinjau dari fungsinya baik sebagai pusat industri, politik, perdagangan, kebudayaan, dan kesehatan (Yunus, 2014). Perkembangan tersebut berbanding lurus dengan jumlah penduduk yang semakin tinggi. Pada periode 10 tahun yaitu dari tahun 2008 hingga 2018, Kota Yogyakarta mengalami peningkatan kepadatan penduduk dengan nilai 9.933 jiwa $/ \mathrm{km}^{2}$ pada tahun 2008 menjadi 13.007 jiwa $/ \mathrm{km}^{2}$ (BPS, 2018b). Keberlangsungan aktivitas sosial, ekonomi, pendidikan, dan budaya masyarakat perlu didukung oleh kondisi lingkungan alamnya (Trencher, 2019).

Letak Kota Yogyakarta yang berdekatan dengan gunung api aktif di bagian utara (Gunung Merapi) mempunyai potensi dampak bahaya. Bagian selatan Yogyakarta terdapat sesar aktif yang merupakan pergerakan dari lempeng. Hal ini menjadikan Kota Yogyakarta memiliki potensi multi bahaya dan bencana (BPBD, 2020). Potensi bencana di suatu wilayah dapat menimbulkan dampak kerugian harta benda hingga dapat menimbulkan korban jiwa (Irawan et al., 2020; Sunardi \& Sulastri, 2015). Kota Yogyakarta juga menjadi wilayah yang memiliki indeks rawan bencana dengan klasifikasi tinggi secara nasional (BPBD, 2019). Pemahaman dan informasi bencana penting disampaikan kepada masyarakat untuk meningkatkan kewaspadaan masyarakat terhadap bencana (Cahyadi et al., 2012). Informasi kebencanaan atau pemahaman literasi bencana merupakan salah satu langkah pencegahan bencana, dengan memberikan pemahaman ciri-ciri bencana (Afrian \& Islami, 2019; Febriarta \& Wibowo, 2021).

Penghimpunan informasi kebencanaan dapat diperoleh dari kejadian atau sejarah kebencanaan, salah satunya dengan wawancara masyarakat yang terdampak suatu bencana (Pham et al., 2020). Teknik penghimpunan infromasi langsung dari masyarakat dapat dilakukan dengan partisipasi masyarakat atau keikutsertaan kelompok dalam melakukan inventarisasi kebencanaan (BNPB, 2017; Taufiq et al., 2017). Keterlibatan atau partisipasi masyarakat dalam pemetaan potensi dan mitigasi kebencanaan dapat menghasilkan informasi yang detail dan dapat disesuaikan dengan kondisi sumber daya dan daya dukung dalam langkah mitigasi kebencanaan (Suherningtyas et al., 2021).

Penelitian tentang bencana di wilayah perkotaan telah dilakukan seperti pada penelitian tentang pemetaan tingkat kerentanan Kota Semarang terhadap bencana alam yang menunjukkan bahwa Kota Semarang memiliki kerawanan sedang (Taufiq et al., 2017). Selain itu pada penelitian lain tentang pemetaan kesiapsiagaan wilayah kota dalam menghadapi bencana pada tahun 2019 yang menunjukkan bahwa masyarakat kota memahami adanya pemetaan kebencanaan di suatu wilayah (Cariolet et al., 2019). Evaluasi untuk mengurangi risiko bencana juga dilakukan di Nuku'alofa Tonga yang menunjukkan bahwa infrastruktur mendukung dalam mengurangi risiko bencana banjir di wilayah tersebut (Fakhruddin et al., 2019). Ketiga metode pengambilan data kebencanaan tersebut didasarkan atas survei dan wawancara kejadian kebencanaan, belum dilakukan tahapan wawancara mendalam terstruktur. Oleh karena itu penelitian ini berfokus untuk mendapatkan informasi kebencanaan yang seluas-luasnya dengan pendekatan Fokus Grup Diskusi (FGD) atau partisipasi dari narasumber warga terdampak dan komunitas tanggap bencana pada skala desa. Sarana informasi kebencanaan menjadi salah satu penunjang dalam peningkatan kewaspadaan dan kesiapsiagaan bencana masyarakat (Ardiansyah, 2017). Selain itu, 
Jurnal Pendidikan Geografi:

Kajian, Teori, dan Praktek dalam Bidang Pendidikan dan Ilmu Geografi

27(1), 2022, 26-37

penyediaan informasi kebencanaan menjadi salah satu program penting dalam penanggulangan bencana, hal ini bertujuan untuk mengurangi risiko bencana sesuai dengan Peraturan Kota Yogyakarta nomor 15 tahun 2009 tentang penanggulangan bencana daerah (Pemerintah Kota Yogyakarta, 2013). Implementasi dari undang-undang tersebut adalah penyediaan informasi kebencanaan dan mitigasi.

Kelurahan Pringgokusuman adalah kelurahan di Yogyakarta yang memiliki kepadatan penduduk tinggi yaitu $27.178 \mathrm{jiwa} / \mathrm{km}^{2}$ dengan luas lahan terbangun mencapai $89 \%$ dari total lahan yang ada (BPS, 2018a). Disisi lain secara geografis Kelurahan Pringgokusuman berada pada bantaran Sungai Winongo yang memiliki hulu di Gunung Merapi yang merupakan gunung api aktif dan berada di kawasan sesar opak yang berada di sisi selatan Yogyakarta dimana aktivitas sesar tersebut dapat mengakibatkan gempa bumi. Kelurahan Pringgokusuman berada pada daerah yang rawan bencana, namun Kelurahan Pringgokusuman belum memiliki peta rawan bencana secara detail dengan batas kampung yang ada di Kelurahan Pringgokusuman. Berdasarkan hal tersebut maka diperlukan identifikasi dan pengkajian potensi bencana di Kelurahan Pringgokusuman sebagai wilayah perkotaan yang rawan terjadi bencana. Penelitian ini bertujuan untuk mengetahui dasar tentang kebencanaan yang terjadi di Kelurahan Pringgokusuman, Kemantren (Kecamatan) Gedongtengen, Kota Yogyakarta, Provinsi Daerah Istimewa Yogyakarta yang mempunyai kepadatan penduduk tinggi dan merupakan Kawasan padat penduduk. Melalui hasil penelitian ini diharapkan dapat digunakan mengurangi risiko bencana di wilayah perkotaan padat penduduk di Kelurahan Pringgokusuman dan juga sebagai upaya untuk mendukung pembelajaran dan pendidikan mitigasi bencana untuk masyarakat.

\section{Metode}

Lokasi penelitian berada Kelurahan Pringgokusuman, Kemantren (Kecamatan) Gedongtengen, Kota Yogyakarta, Provinsi Daerah Istimewa Yogyakarta sebagai daerah yang memiliki karakteristik perkembangan kota dengan kondisi geografisnya yang berada pada bantaran Sungai Winong di bagian barat (Gambar 1) dengan hulu dari lereng Gunung Merapi dan berada dekat dengan gunung api aktif yaitu Gunung Merapi di bagian utara. Kelurahan Pringgokusuman merupakan kelurahan di Kota Yogyakarta dengan luas $0,46 \mathrm{~km}^{2}$ dan total penggunaan lahan bangunan permanen mencapai $0,3985 \mathrm{~km}^{2}$ atau $86,7 \%$ dari luas wilayahnya. Jumlah penduduk Pringgokusuman adalah 12.549 jiwa (BPS, 2019).

Pengumpulan data dilakukan dengan observasi, wawancara mendalam, dan Fokus Grup Diskusi (FGD). Observasi dilakukan dengan cara mengumpulkan data dengan mengamati dan memperhatikan objek penelitian baik secara langsung maupun tidak langsung serta mengadakan pencatatan tentang hasil pengamatan tersebut secara sistematis (Setiadi, 2020). Wawancara dilakukan secara indepth interview dengan key person yang memahami informasi sesuai tujuan penelitian. Melalui wawancara, peneliti dapat mengetahui hal-hal yang lebih mendalam tentang partisipan dalam menginterpretasikan situasi dan fenomena yang terjadi. Hal ini tidak dapat ditemukan melalui observasi (Arif et al., 2017; Firmansyah et al., 2019). Keuntungan yang diperoleh dari wawancara adalah peneliti dapat dengan fleksibel menggunakan pengetahuannya, keahlian, keterampilan interpersonal untuk mengeksplorasi ketertarikan terhadap ide baru yang muncul atau tema yang sedang dikaji (Munajati et al., 2021). 
Jurnal Pendidikan Geografi:

Kajian, Teori, dan Praktek dalam Bidang Pendidikan dan Ilmu Geografi

$27(1), 2022,26-37$

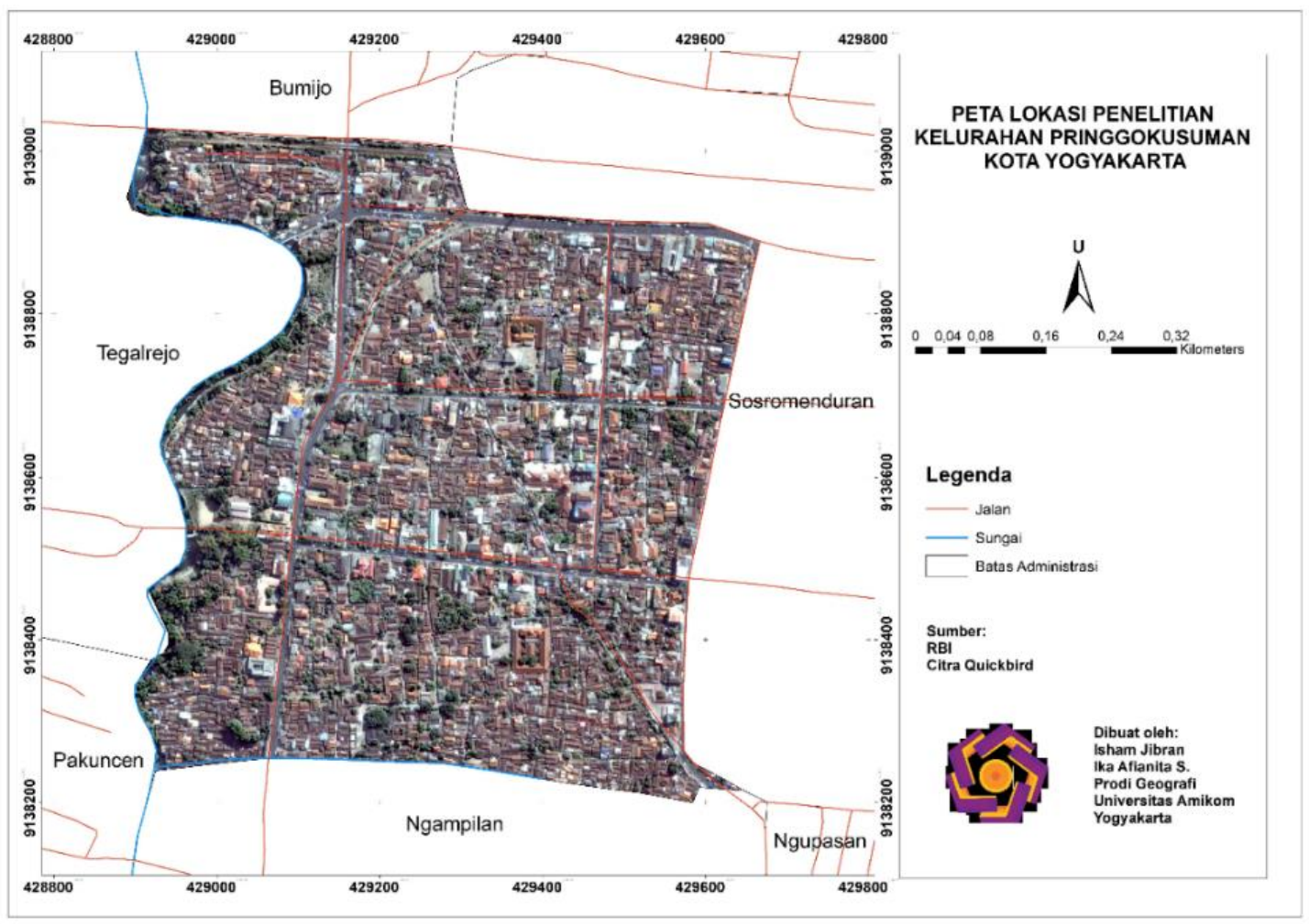

Gambar 1. Lokasi Daerah Penelitian

Narasumber informasi yang digunakan dalam pemetaan partisipasi adalah key person yang memiliki pengetahuan tentang masalah dan tujuan penelitian (Febriarta et al., 2020). Sehingga ditentukan key person penelitian antara lain kepala Kelurahan Pringgokusuman, ketua Kampung Tangguh Bencana (KTB), bidang media center Badan Nasional Penanggulangan Bencana (BPBD) DIY. Dalam penggalian informasi dasar dilakukan secara Focus Group Discussion (FGD) yang dilakukan bersama secara kelompok. Pendekatan yang digunakan adalah dengan diskusi permasalahan penelitian sehingga diperoleh data atau jenis kebencanaan yang pernah terjadi maupun yang berpotensi menjadi bencana. Kegiatan FGD pada penelitian ini dilakukan pada skala kelurahan, yaitu berada di Kelurahan Pringgokusuman, bersama masyarakat anggota Kampung Siaga Bencana (KSB) Pringgokusuman. Melalui FGD diharapkan mendapat data yang optimal sesuai dengan permasalahan kebencanaan yang dihadapi langsung oleh masyarakat (Andriany et al., 2015).

Hasil dari kegiatan FGD berupa informasi dasar kebencanaan kemudian dianalisis deskriptif kualitatif. Pada tahap analisis data, dilakukan penjabaran permasalahan penelitian secara deskriptif kualitatif setelah memperoleh pengetahuan yang cukup terkait objek penelitian. Rekapitulasi hasil FGD kemudian ditambahkan informasi keruangan (spasial) dengan informasi lokasi koordinat berupa titik maupun area tentang kebencanaan maupun potensi bencana. Hasil analisis menggambarkan tentang analisis data keruangan (spasial) kebencanaan di Kelurahan Pringgokusuman. Diagram alir kegiatan penelitian partisipatif dalam mitigasi kebencanaan di Kelurahan Pringgokusuman Kota Yogyakarta disajikan pada Gambar 2. 
Jurnal Pendidikan Geografi:

Kajian, Teori, dan Praktek dalam Bidang Pendidikan dan Ilmu Geografi

27(1), 2022, 26-37

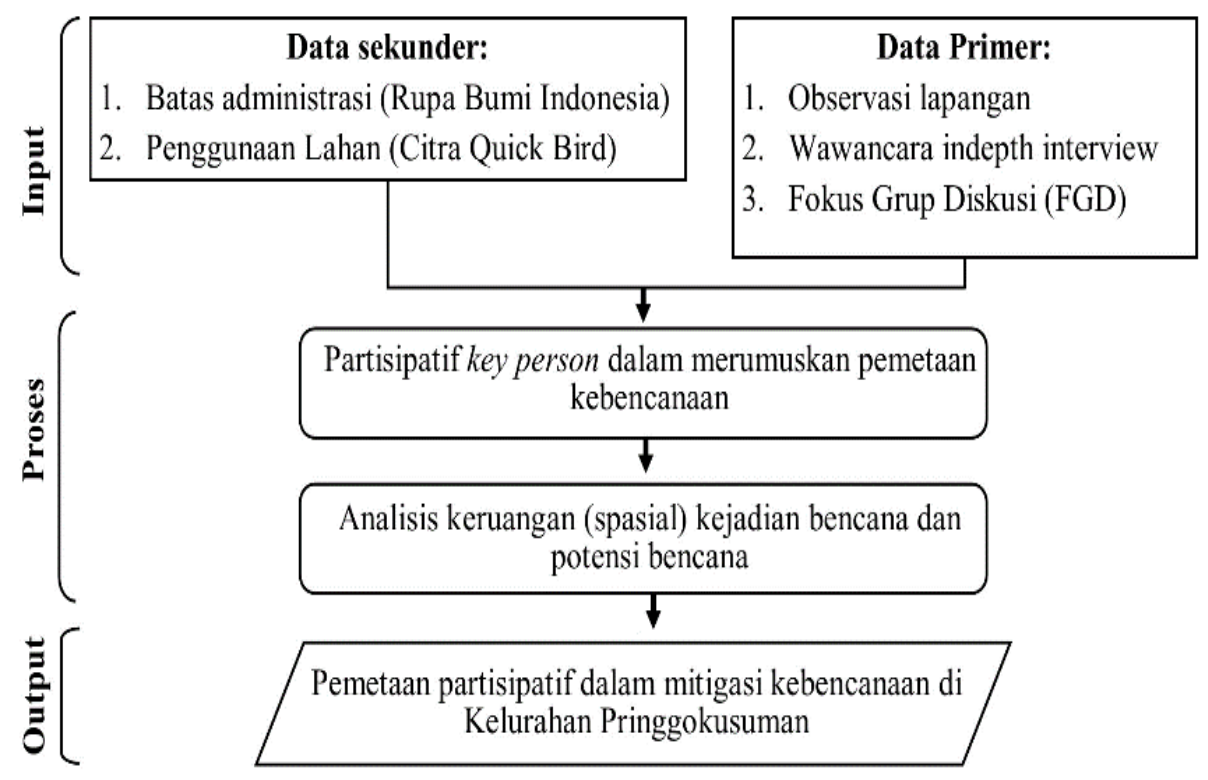

Gambar 2. Diagram Alir Penelitian

\section{Hasil dan Pembahasan}

\subsection{Kondisi Kebencanaan Wilayah Perkotaan di Kota Yogyakarta}

Kelurahan Pringgokusuman terletak bersebelahan dengan kegiatan pusat kota Yogyakarta. Dampak dari lokasi yang dekat dengan pusat kota tersebut mengakibatkan pertumbuhan wilayah perkotaan tumbuh pesat melalui kegiatan ekonomi, sosial, dan kebudayaan. Perkembangan Kota Yogyakarta juga dipengaruhi oleh kegiatan pusat pendidikan yang berdampak meningkatnya aktivitas, yang terjadi hingga berbanding lurus terhadap kenaikan penggunaan lahan berupa permukiman dan jumlah penduduk (Prastowo, 2016). Kondisi tersebut perlu diimbangi oleh pengembangan wilayah kota yang berkelanjutan dengan tidak melupakan aspek ekologikal (Ni'mah \& Lenonb, 2017). Ekologi dapat diartikan interaksi antar makhluk hidup satu dengan lainnya maupun interaksi makhluk hidup dengan lingkungan (Kurniawan, 2015). Kebencanaan menjadi salah satu aspek penting yang perlu dipahami oleh masyarakat. Hal ini juga berhubungan dengan lokasi geografis Yogyakarta dekat dengan Gunung Merapi, yang mempunyai potensi gempa (Santosa \& Muta'ali, 2014).

Beberapa kejadian bencana tidak dapat diprediksi kapan terjadi, sehingga pengetahuan dan kewaspadaan masyarakat penting dimiliki untuk mengurangi dampak risiko bencana yang dapat ditimbulkan (Giyarsih, 2013). Kejadian bencana di Kota Yogyakarta sendiri tertinggi adalah angin kencang, namun berbagai potensi bencana lainnya juga dijumpai antara lain banjir, tanah longsor, angin kencang, dan gempa bumi (BNPB, 2017). Grafik kejadian bencana Kota Yogyakarta dapat dilihat pada Gambar 3, melalui grafik tersebut dapat dilihat berbagai jenis bencana yang dapat terjadi di wilayah Kota Yogyakarta. Kelurahan Pringgokusuman menjadi salah satu kelurahan yang membutuhkan data kebencanaan sebagai wujud kesiapsiagaan masyarakat dalam menghadapi bencana. Kebutuhan data kebencanaan membantu masyarakat lebih waspada terhadap kejadian bencana yang sewaktu-waktu dapat datang. 


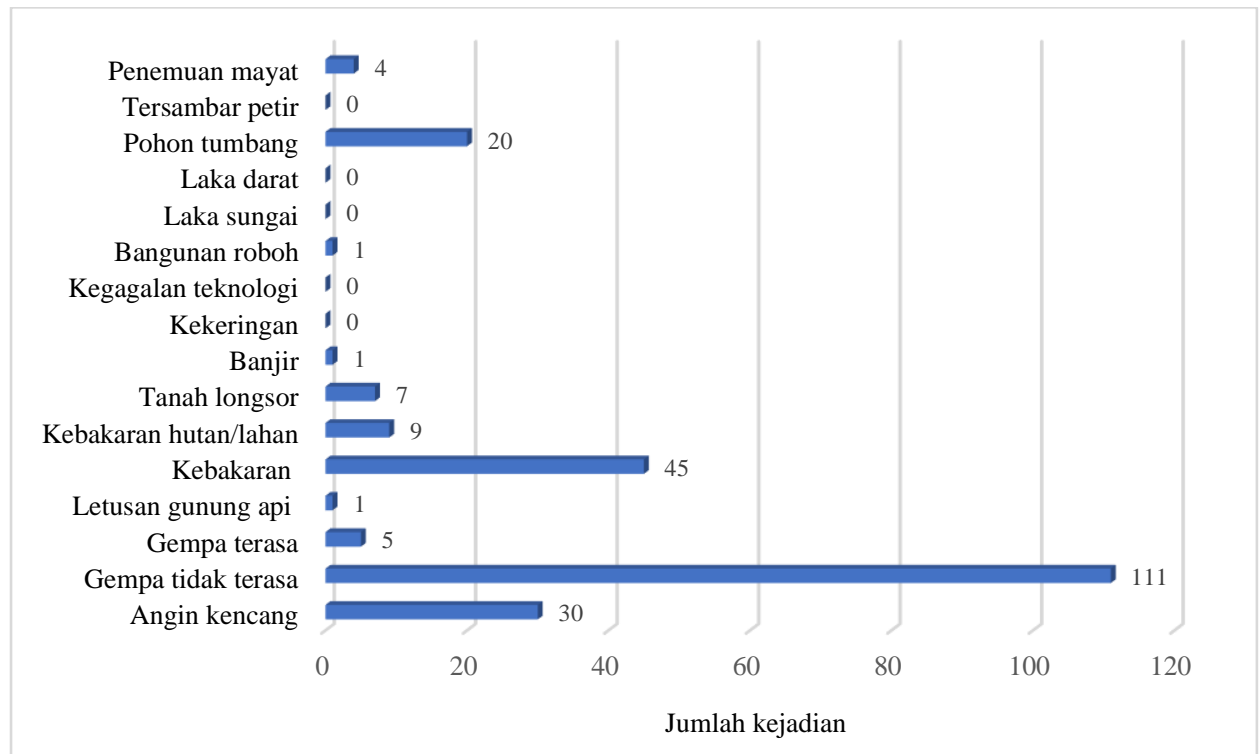

\section{Gambar 3. Rekapitulasi Kejadian Bencana di Kota Yogyakarta} Sumber: BNPB (2017)

\subsection{Analisis Data Spasial Bencana Berbasis Masyarakat}

Kelurahan Pringgokusuman merupakan salah satu kelurahan yang memiliki Kampung Siaga Bencana (KSB) dari dua kelompok KSB (KSB Pringgokusuman dan KSB Kotabaru) yang dimiliki oleh Kota Yogyakarta. Kelurahan Pringgokusuman ditetapkan oleh Dinas Sosial Provinsi Daerah Istimewa Yogyakarta sebagai kampung siaga bencana sejak tahun 2013. Luas wilayah administrasi Kelurahan Pringgokusuman, Kecamatan Gedongtengen Kota Yogyakarta adalah 46 ha (BPS, 2019). Kelurahan Pringgokusuman terdiri dari 7 kampung yaitu: Notoyudan, Gandoan Lor, Jlagran, Kemetiran Kidul, Kemetiran Lor, Pringgokusuman, dan Sutodirjan. Kelurahan Pringgokusuman merupakan wilayah yang padat permukiman dengan peruntukan lahan pemukiman mencapai 41 ha. Berdasarkan interpretasi citra optis terhadap penggunaan lahan (Gambar 1) dan BPS (2019) luas penggunaan lahan didominasi oleh permukiman dengan luas $87 \%$. Kondisi tersebut termasuk kawasan permukiman padat penduduk (Sudiana et al., 2018). Lahan terbuka banyak ditemukan di sempadan sungai dan tanggul alam sungai. Luasan lahan terbuka semakin berkurang, dikarenakan banyak yang sudah beralih fungsi sebagian menjadi bangunan. Perbandingan penggunaan lahan di Kelurahan Pringgokusuman disajikan pada Gambar 4.

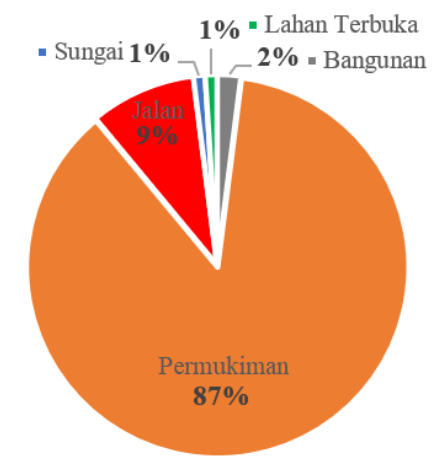

Gambar 4. Peruntukan Lahan di Kelurahan Pringgokusuman 
Jurnal Pendidikan Geografi:

Kajian, Teori, dan Praktek dalam Bidang Pendidikan dan Ilmu Geografi

27(1), 2022, 26-37

Pada Gambar 4 dapat dilihat bahwa kondisi pemukiman sangat padat di lokasi penelitian sehingga lahan kosong atau Ruang Terbuka Hijau (RTH) sangat terbatas. Kondisi ini disebabkan oleh meningkatnya arus migrasi penduduk menuju perkotaan untuk mencari pekerjaan terutama di Kecamatan Pringgokusuman yang berada di pusat wilayah perkotaan Kota Yogyakarta (BPS, 2019; Utari, 2015).

Langkah dalam menghimpun informasi kebencanaan diperoleh dari narasumber antara lain, petugas KSB Pringgokusuman, perangkat desa atau kelurahan, stakeholder dan perwakilan warga. Tahap pertama adalah dengan melakukan wawancara dengan sejumlah warga di Pringgokusuman untuk memperoleh informasi dasar kebencanaan sebanyakbanyaknya. Tahap kedua, wawancara dengan petugas KSB Pringgokusuman, perangkat desa atau kelurahan, dan stakeholder dengan cara FGD dilakukan untuk menetapkan potensi kebencanaan dan langkah mitigasi. Hasil dari FGD, diperoleh hasil kebencanaan yang sering terjadi antara lain: banjir (luapan Sungai Winongo), kebakaran, angin kencang, gempabumi dan masalah kesehatan berupa infeksi saluran pernapasan atas (ISPA), diare dan demam berdarah.

Bencana gempa bumi, dimungkinkan terjadi karena Kelurahan Pringgokusuman berada di kawasan sesar opak dan juga berada dekat dengan Gunung Merapi, sehingga kejadian gempa bumi rawan terjadi di Kelurahan Pringgokusuman seperti pada Gambar 3. Dampak dari gempa bumi di Kelurahan Pringgokusuman antara lain timbulnya keretakan tembok rumah, bergesernya genteng rumah. Adaptasi masyarakat Kelurahan Pringgokusuman terhadap gempa dengan berlindung dibawah pondasi yang kuat seperti meja, dan bila berada di luar bangunan berkumpul di tempat yang lapang.

Kelurahan Pringgokusuman memiliki kepadatan tinggi pada penggunaan lahan permukiman. Permukiman dengan kepadatan yang tinggi memiliki risiko bahaya yang berbanding lurus (tinggi), seperti kebakaran yang diakibatkan hubungan arus pendek (BNPB, 2016). Kebakaran terjadi karena adanya pertemuan arus pendek listrik, kebocoran pipa gas, dan kebakaran dari sumber api (pembakaran sampah atau lilin) (Deni et al., 2013). Sudiana et al., (2018) juga menyebutkan bahwa keterdapatan vegetasi yang kering seperti semak atau belukar dapat memicu risiko bencana kebakaran. Faktor angin kencang juga berpotensi meningkatkan risiko membesarnya kebakaran pada saat terjadi bencana kebakaran (Deni et al., 2013).

Kerawanan bencana kesehatan masyarakat, antara lain: ISPA, diare dan demam berdarah juga mencakup seluruh kampung yang ada di Kelurahan Pringgokusuman. Hal ini terjadi karena lingkungan yang kotor dan adanya genangan air yang menimbulkan jentikjentik nyamuk. Genangan air banyak terbentuk di daerah sempadan Sungai Winong yang terdapat di bagian barat kampung. Demam berdarah menunjukkan jumlah yang menurun sebanding dengan tingkat kebersihan kampung dan kesadaran akan kebersihan, salah satu program kebersihan adalah program kali bersih (Prokasih) yang dijalankan bersama oleh warga dan oleh Dinas Lingkungan Hidup (DLH) Kota Yogyakarta.

Berdasarkan hasil pemetaan partisipatif rawan bencana banjir mencakup kampung yang berada di bantaran Sungai Winongo pada bagian barat dan bantaran saluran air atau selokan pada bagian selatan (Gambar 5). Seperti yang terjadi pada tanggal 14 Februari 2020, beberapa kampung di Kelurahan Pringgokusuman mengalami bencana banjir akibat hujan deras yang melanda Yogyakarta, kondisi ini menyebabkan luapan air yang melebihi volume 


\section{Jurnal Pendidikan Geografi:}

Kajian, Teori, dan Praktek dalam Bidang Pendidikan dan Ilmu Geografi

$27(1), 2022,26-37$

saluran irigasi sehingga terjadi banjir di rumah warga. Adapun ketinggian banjir mencapai 10$20 \mathrm{~cm}$ (Gambar 6). Selokan yang terdapat di selatan Kelurahan Pringgokusuman memiliki lebar 0,4-1 m dengan kedalaman 0,3 m, kondisi tersebut dapat mudah meluap jika intensitas hujan tinggi kemudian kebersihan selokan juga mempengaruhi laju air. Selain kondisi tersebut kondisi topografi di bagian selatan memiliki elevasi yang lebih rendah, sehingga kampung di bagian selatan rawan tergenang. Langkah pengurangan bencana banjir luapan saluran adalah dengan pemantauan kebersihan saluran drainase, agar tidak menghambat laju air. Edukasi masyarakat tentang pentingnya memelihara kebersihan saluran drainase, dan pemberian papan himbauan tidak membuang sampah di saluran drainase.

Berdasarkan hasil FGD diketahui bahwa kampung yang rawan mengalami banjir luapan adalah Notoyudan dan Sutodirjan. Banjir luapan juga rawan terjadi di bantaran Sungai Winongo, hal ini terjadi apabila curah hujan tinggi dan juga dipengaruhi oleh adanya endapan lahar dingin jika terjadi erupsi Gunung Merapi. Langkah dalam pengurangan bahaya bencana banjir luapan Sungai Winongo dengan pemantauan berkala pada saat hujan di hulu yang bekerja sama dengan komunitas pemantauan Gunung Merapi.

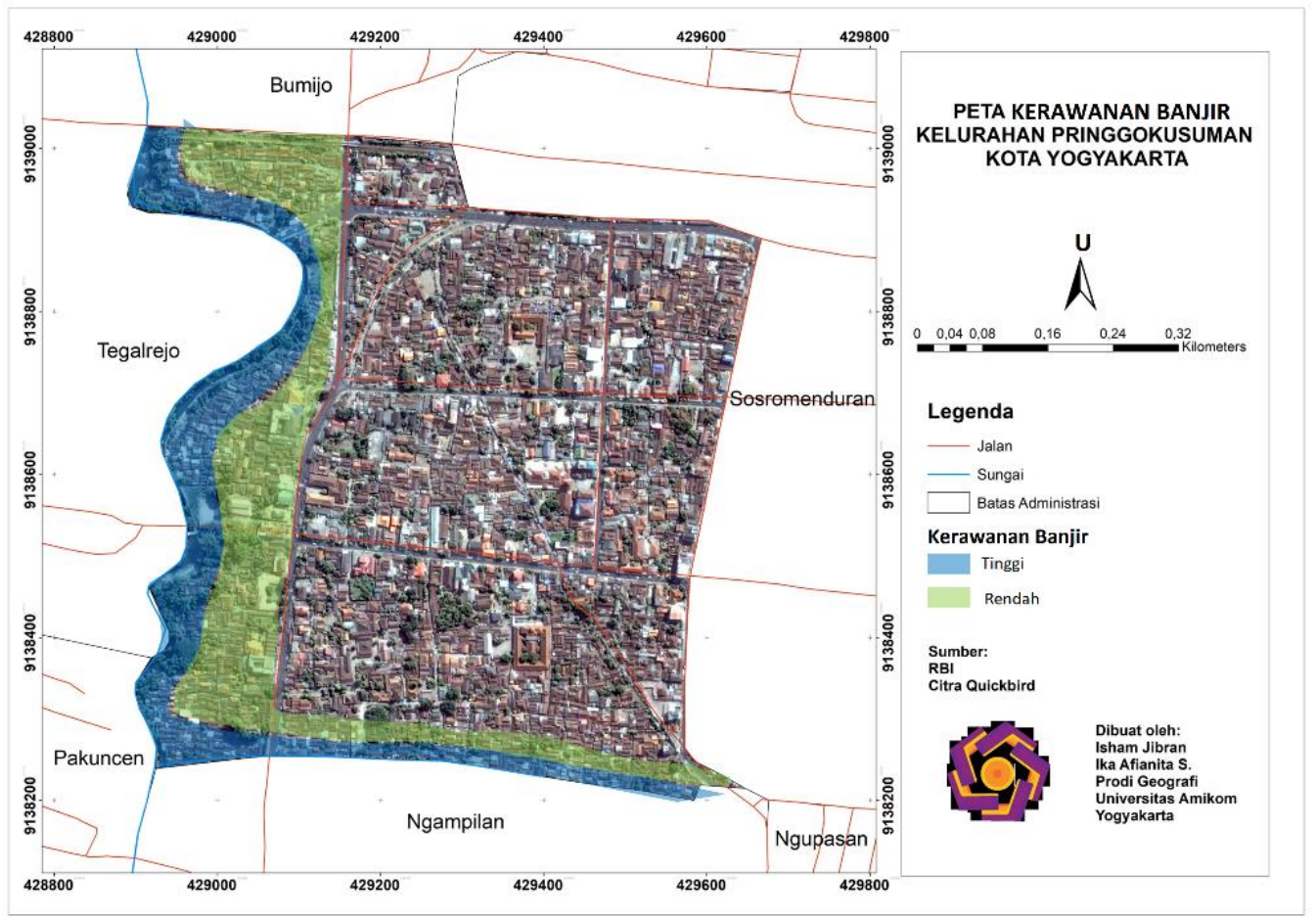

Gambar 5. Peta Partisipatif Rawan Bencana Banjir

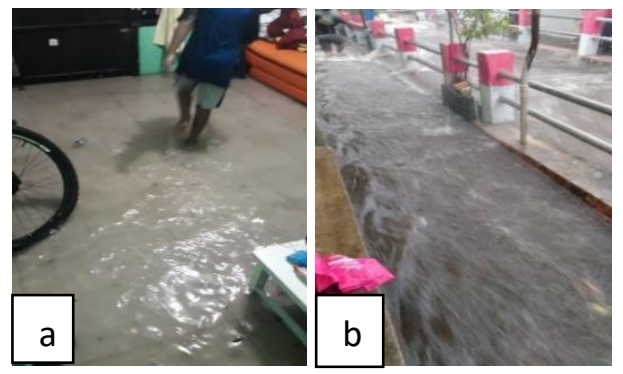

Gambar 6. a) Banjir yang Menggenangi Rumah Warga; b) Banjir Luapan dari Selokan 
Berdasarkan pemetaan hasil partisipasi warga dan FGD diketahui bahwa daerah bantaran sungai juga rawan terjadi tanah longsor. Kondisi tersebut dipengaruhi oleh kemiringan bantaran sungai yang terjal, yang mengakibatkan pergerakan tanah atau longsor. Kemiringan lereng tersebut mempunyai risiko yang tinggi bila memiliki kemiringan yang terjal dan tidak terdapat pondasi yang kuat. Kampung yang berada pada kawasan rawan banjir dan tanah longsor dengan risiko tinggi adalah Jlagran dan Notoyudan seperti pada Gambar 7. Pembangunan tanggul dan infrastruktur yang kuat pada bantaran sungai dapat mengurangi risiko terjadinya tanah longsor. Mitigasi pada zona kerawanan longsor dengan edukasi ciri-ciri longsor, pemberian tanda bahaya longsor pada zona dengan sifat kemiringan lereng yang terjal, tidak menggunakan lahan dengan kemiringan terjal dan menjauhi dari bantaran sungai, memberikan jalur evakuasi dan arah titik kumpul yang aman dan secara kebijakan dapat mengesahkan dengan penetapan zona bahaya longsor dan tidak diperuntukan sebagai aktivitas maupun permukaan melalui pengesahan peraturan bupati.

Hasil pemetaan partisipatif dengan FGD menunjukkan potensi kebencanaan di Kelurahan Pringgokusuman bersifat multi bencana. Berbagai kerawanan bencana yang ada di Kelurahan Pringgokusuman perlu dilakukan kegiatan mitigasi bencana baik secara struktural maupun non struktural (Fakhruddin et al., 2019). Selain langkah awal dengan melakukan identifikasi data spasial kebencanaan, melalui data tersebut dapat dilakukan berbagai program antisipasi untuk meningkatkan kewaspadaan dan kesiapsiagaan bencana seperti pembangunan infrastruktur yang kuat mampu menahan debit aliran sungai seperti tanggul bantaran sungai, bangunan rumah yang tahan gempa, dan pembuatan jalur evakuasi khusus jika terjadi bencana (Arif et al., 2017). Adapun pembuatan dan pemeliharaan saluran irigasi juga perlu dilakukan untuk menghindari tersumbatnya aliran air jika terjadi hujan. Ruang terbuka hijau dan peningkatan vegetasi perlu dilakukan di sekitar lingkungan Kelurahan Pringgokusuman untuk meningkatkan absorpsi udara sehingga mampu mengurangi dampak terjadinya cuaca ekstrim di sekitar Kelurahan Pringgokusuman. Analisis data spasial untuk mitigasi bencana di Kelurahan Pringgokusuman dapat menjadi informasi dasar dalam penanggulangan bencana agar meningkatkan kewaspadaan masyarakat apabila bencana sewaktu-waktu datang.

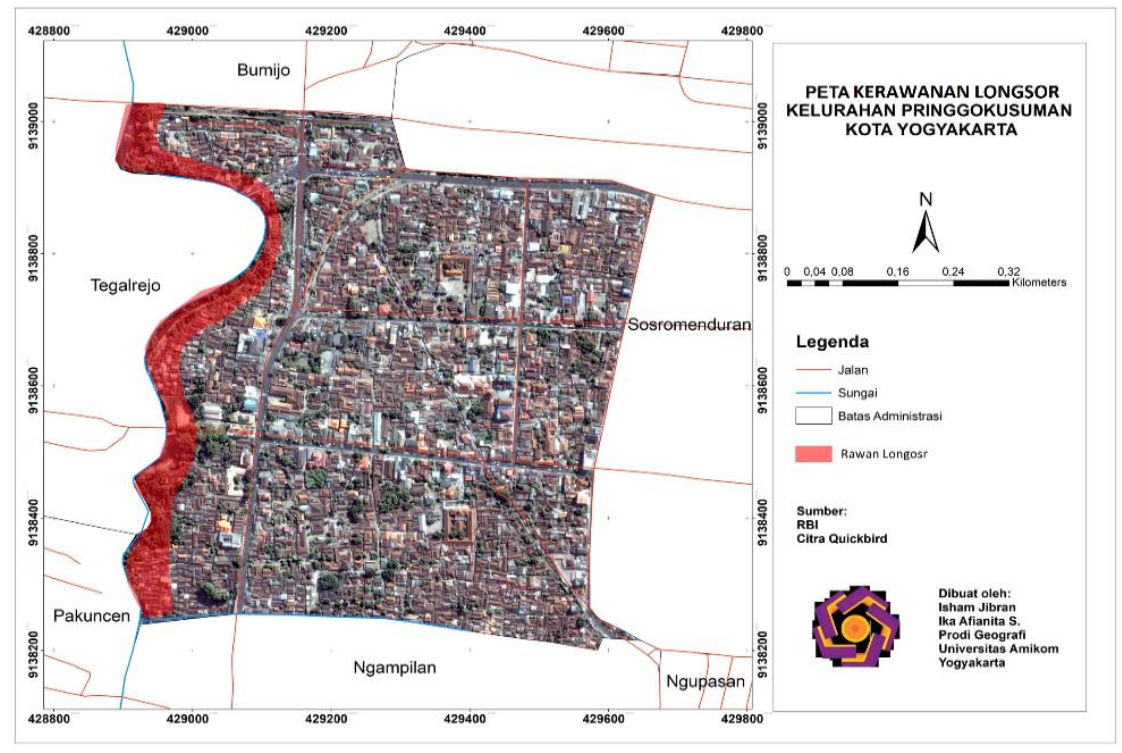

Gambar 7. Peta Partisipatif Rawan Bencana Tanah Longsor 


\section{Simpulan}

Kelurahan Pringgokusuman merupakan salah satu daerah di Kota Yogyakarta yang memiliki multi bencana. Dua kampung di Kelurahan Pringgokusuman, yaitu Jlagran dan Notoyudan berada di bantaran Sungai Winongo yang memiliki kerentanan bencana tanah longsor dan banjir luapan sungai, sedangkan Kampung Notoyudan dan Kemetiran Kidul rawan terjadi banjir luapan karena berada di sekitar saluran irigasi. Program antisipasi untuk meningkatkan kewaspadaan dan kesiapsiagaan bencana dapat dilakukan, seperti pembangunan infrastruktur yang mampu menahan debit aliran sungai seperti tanggul di sekitar bantaran sungai, pembangunan rumah dengan prinsip tahan gempa, dan pembuatan jalur evakuasi jika terjadi bencana. Adapun pembuatan dan pemeliharaan saluran irigasi juga perlu dilakukan untuk menghindari tersumbatnya aliran air jika terjadi hujan. Ruang terbuka hijau dan vegetasi perlu dilakukan di sekitar lingkungan Kelurahan Pringgokusuman untuk meningkatkan absorpsi udara sehingga mampu mengurangi dampak terjadinya cuaca ekstrim di sekitar Kelurahan Pringgokusuman. Temuan penelitian ini diharapkan dapat digunakan untuk mengurangi risiko bencana di pedesaan Kelurahan Pringgokusuman, serta sebagai sarana pendidikan dan mitigasi bencana bagi masyarakat umum. Selain itu, Penelitian ini dapat menjadi materi ajar dalam pembelajaran Geografi yang berkaitan dengan tema bencana.

\section{Daftar Rujukan}

Afrian, R., \& Islami, Z. R. (2019). Peningkatan potensi mitigasi bencana dengan penguatan kemampuan literasi kebencanaan pada masyarakat Kota Langsa. Jurnal Pendidikan Geografi: Kajian, Teori, dan Praktek dalam Bidang Pendidikan dan Ilmu Geografi, 24(2), 132-144. https://doi.org/10.17977/um017v24i22019p132

Andriany, D., Hasibuan, L. S., \& Rahayu, S. E. (2015). Pengembangan model pendekatan partisipatif dalam memberdayakan masyarakat miskin Kota Medan untuk memperbaiki taraf hidup. Kumpulan Penelitian dan Pengabdian Dosen, 1(1).

Ardiansyah, A. D. (2017). Kesipasiagaan guru SMAN 1 Prambanan dalam menghadapi bencana gempa bumi. Jurnal Pendidikan Geografi: Kajian, Teori, dan Praktek dalam Bidang Pendidikan dan Ilmu Geografi, 22(2), 120-133.

Arif, D. A., Mardiatno, D., \& Giyarsih, S. R. (2017). Kerentanan masyarakat perkotaan terhadap bahaya banjir di Kelurahan Legok Kecamatan Telanipura Kota Jambi. Majalah Geografi Indonesa, 31(1), 1-11.

BNPB. (2016). Risiko Bencana Indonesia. Badan Nasional Penanggulangan Bencana (BNPB).

BNPB. (2017). Data dan Informasi Bencana Indonesia. Badan Nasional Penanggulangan Bencana (BNPB).

BPBD. (2019). Laporan kinerja instansi pemerintah tahun 2019. Badan Penanggulangan Bencanan Daerah.

BPBD. (2020). Infografis Daerah Istimewa Yogyakarta tahunan 2020. Badan Penanggulangan Bencanan Daerah.

BPS. (2018a). Kecamatan Gedongtengen dalam Angka 2018. BPS.

BPS. (2018b). Provinsi DIY dalam Angka 2018. BPS.

BPS. (2019). Kecamatan Gedongtengen dalam Angka 2019. BPS.

Cahyadi, A., Afianita, I., Gamayanti, P., \& Fauziah, S. (2012). Evaluasi tata ruang Pesisir Sadeng Gunung Kidul: Perspektif pengurangan risiko bencana. Seminar Nasional SCAN (Suistanable, Culture, Architecture, and Nature) Ke-3, 1-8.

Cariolet, J. M., Vuillet, M., \& Diab, Y. (2019). Mapping urban resilience to disasters - A review. Sustainable Cities and Society, 51(August), 101746. https://doi.org/10.1016/j.scs.2019.101746

Czúcz, B., Haines-Young, R., Kiss, M., Bereczki, K., Kertész, M., Vári, Á., Potschin-Young, M., \& Arany, I. (2020). Ecosystem service indicators along the cascade: How do assessment and mapping studies position their indicators? Ecological Indicators, 118, 106729. https://doi.org/10.1016/J.ECOLIND.2020.106729

Deni, D., Pane, M., \& Rejoni, R. (2013). Pendekatan penanggulangan kebakaran pada permukiman padat perkotaan. Jurnal Arsitekno, 1(1), 52-63. https://doi.org/10.29103/arj.v1i1.1238 


\title{
Jurnal Pendidikan Geografi:
}

\section{Kajian, Teori, dan Praktek dalam Bidang Pendidikan dan Ilmu Geografi}

\author{
$27(1), 2022,26-37$
}

Fakhruddin, B., Reinen-Hamill, R., \& Robertson, R. (2019). Extent and evaluation of vulnerability for disaster risk reduction of urban Nuku'alofa, Tonga. Progress in Disaster Science, 2, 100017. https://doi.org/10.1016/j.pdisas.2019.100017

Febriarta, E., \& Oktama, D. R. (2020). Pemetaan daya dukung lingkungan berbasis jasa ekosistem penyedia pangan dan air bersih di Kota Pekalongan. Jurnal Ilmu Lingkungan, 18(2), 283-289. https://doi.org/10.14710/JIL.18.2.283-289

Febriarta, E., Oktama, R., \& Purnama, S. (2020). Analisis daya dukung lingkungan berbasis jasa ekosistem penyediaan pangan dan air bersih di Kabupaten Semarang. Geo Media: Majalah Ilmiah dan Informasi Kegeografian, 18(1), 12-24. https://doi.org/10.21831/GM.V18I1.30612

Febriarta, E., \& Wibowo, Y. A. (2021). Kerentanan gerakan tanah menggunakan teknik geospasial statistik di Macang Pacar, Nusa Tenggara Timur. Jurnal Geografi, 18(1), 9-20. https://doi.org/https://doi.org/10.15294/jg.v18i1.26234

Firmansyah, Syarifudin, D., \& Rohjan, J. (2019). The risk assessment of multi hazard area: A Case of mitigation consider in spatial planning of Bukittinggi City. Indonesian Journal of Geography, 51(3), 304-323. https://doi.org/10.22146/IJG.33298

Giyarsih, S. R. (2013). Aspek sosial banjir lahar. Gadjah Mada University Press.

Irawan, L. Y., Roys, I., Rosyadi, I., \& Siswanto, Y. (2020). Analisis kerawanan longsor di Kecamatan Jabung, Kabupaten Malang. Jurnal Pendidikan Geografi: Kajian, Teori, dan Praktek dalam Bidang Pendidikan dan Ilmu Geografi, 25(2), 102-113.

Kurniawan, A. (2015). Keistimewaan lingkungan Daerah Istimewa Yogyakarta. Gadjah Mada University Press.

Munajati, S. L., Kartodihardjo, H., Saleh, M. B., \& Nurwadjedi, N. (2021). Ecosystem services dynamics in Bogor Regency. Indonesian Journal of Geography, 53(2), 264-273. https://doi.org/10.22146/IJG.64493

Ni'mah, N. M., \& Lenonb, S. (2017). Urban greenspace for resilient city in the future: Case study of Yogyakarta City. IOP Conference Series: Earth and Environmental Science. https://doi.org/10.1088/1755$1315 / 70 / 1 / 012058$

Pemerintah Kota Yogyakarta. (2013). Peraturan Daerah Kota Yogyakarta nomor 15 tahun 2009 tentang penanggulangan bencana daerah.

Pham, N. T. T., Nong, D., Sathyan, A. R., \& Garschagen, M. (2020). Vulnerability assessment of households to flash floods and landslides in the poor upland regions of Vietnam. Climate Risk Management, 28. https://doi.org/10.1016/j.crm.2020.100215

Prastowo, P. (2016). Analisis pengaruh pertumbuhan ekonomi terhadap penggunaan lahan perkotaan pendekatan spatial econometrics: Studi kasus perkotaan DIY, 2011. Jurnal Ekonomi \& Studi Pembangunan, 17(1), 22-30. https://doi.org/10.18196/jesp.17.1.2458

Rachmawati, R., Ramadhan, E. R., \& Rohmah, A. 'A. (2018). Aplikasi smart province "Jogja Istimewa": Penyediaan informasi terintegrasi dan pemanfaatannya. Majalah Geografi Indonesia, 32(1), 14. https://doi.org/10.22146/mgi.31662

Santosa, L. W., \& Muta'ali, L. (2014). Bentang alam dan bentang budaya. BPFG UGM.

Setiadi. (2020). Migration, landscape dynamics, and fishermen livelihood: A case study at East Kalimantan. Indonesian Journal of Geography, 52(3), 350-359. https://doi.org/10.22146/IJG.54700

Setyaningrum, A., \& Febriarta, E. (2019). Analisis kesesuaian dan daya dukung ekowisata pantai kategori rekreasi Pantai Kuwaru Kabupaten Bantul Yogyakarta. Seminar Nasional Pengelolaan Pesisir dan Daerah Aliran Sungai Ke-5, 5(March), 36-41. https://doi.org/https://doi.org/10.17605/0SF.IO/82PTU

Sudiana, N., Umbara, R. P., \& Zahro, Q. (2018). Kajian kapasitas daerah terhadap bencana kebakaran perkotaan (studi kasus di Kecamatan Cakung, Kota Jakarta Utara). Jurnal Sains dan Teknologi Mitigasi Bencana, 13(1), 44-56. https://doi.org/10.29122/jstmb.v13i1.2910

Suherningtyas, I. A., Pitoyo, A. J., Permatasari, A. L., \& Febiarta, E. (2021). Kapasitas ketahanan masyarakat dalam menghadapi bencana pandemi COVID-19 di wilayah perkotaan (studi kasus: Kampung Krasak RT 16, RW 04, Kelurahan Kotabaru, Kecamatan Gondokusuman, Kota Yogyakarta). Jurnal Ketahanan Nasional, 27(1), 16-38.

Sunardi, B., \& Sulastri, S. (2015). Deagregasi bahaya gempa bumi untuk Daerah Istimewa Yogyakarta. Simposium Nasional Sains Geoinformasi IV 2015. 
Jurnal Pendidikan Geografi:

Kajian, Teori, dan Praktek dalam Bidang Pendidikan dan Ilmu Geografi

27(1), 2022, 26-37

Taufiq, A., Setiawan, L. A., Hardisono, U., Aziz, M. N., Khoiruddin, M., Apriyadi, F., Amalia, N., Insani, S. P., Ferdaus, N. N., Wardhani, K. T., \& Maulana, V. Z. (2017). Pemberdayaan masyarakat melalui pengurangan resiko bencana berbasis masyrakat (community-based disaster risk reducation) di Desa Wukirharjo, Kecamatan Prambanan. Prosiding Seminar Nasional UII.

Trencher, G. (2019). Towards the smart city 2.0: Empirical evidence of using smartness as a tool for tackling social challenges. Technological Forecasting and Social Change, 142(April), 117-128. https://doi.org/10.1016/j.techfore.2018.07.033

Utari, M. E. S. (2015). Analisis sistem pusat pelayanan permukiman di Kota Yogyakarta Tahun 2014. JEJAK: Jurnal Ekonomi dan Kebijakan, 8(1). https://doi.org/10.15294/jejak.v8i1.3856

Yunus, H. S. (2014). Klasifikasi kota. Pustaka Pelajar. 